\title{
Constitution of Afghanistan: An Analysis of Educational and Linguistic Provisions
}

\author{
Asghar Khan ${ }^{1}$, Ayaz Ahmad ${ }^{2}$ and Asma Gul ${ }^{3 *}$ \\ 1. Department of Regional Studies, University of Peshawar, Peshawar, Pakistan. \\ 2. Department of English, Abdul Wali Khan University, Mardan, Pakistan. \\ 3. Department of Education, International Islamic University, Islamabad, Pakistan.
}

Published Online: September 26, 2020

\begin{abstract}
The paper analyses the Constitution of 2004 of Afghanistan in the context of Education and Linguistics. It aims to determine the extent of concentration and focus given to the educational and linguistics promotion in the new constitution. The paper also attempts to unearth the features of the language landscape of Afghanistan. It investigates why language and education have become an existential problem in Afghanistan. It also explores how the new constitution ensures the provision of education and language. The article has reviewed the secondary data, mostly the analytical review of the current constitution of Afghanistan in the light of the comparative study of the other related documents and old constitutions. The new constitution provides sufficient evidence of the attention given to education and linguistics promotion. Comparative analyses of the articles of the Constitution of Afghanistan 2004, with the supportive study of other related facts and documents, reveals that the current constitution is better than the previous constitutions in acknowledging the language and education-related issues in post-conflict Afghanistan. The current constitution promotes and preserves the linguistic plurality of Afghanistan. Keeping in view the state's universal education mandate, it not only provides free education but also makes the education mandatory for all of its citizens.
\end{abstract}

Keywords: Afghanistan, Afghan Constitution, Education, Language Rights, Ethnic Conflicts, Ethnic Polarisation, Linguistic Polarisation.

\section{Introduction}

The study evaluates the treatment of education and language in the current constitution of Afghanistan. The concept of free and mandatory education shall promote peace and harmony in Afghanistan. Since the issues about the preservation and usages of the local/regional languages, were not adequately dealt with in the earlier constitutions, it not only resulted in ethnolinguistic polarisation but was also a reason for conflicts amid regional groups. The legislators of the present constitution were mindful that the proper management and preservation of the languages and provision of compulsory and free education would be a binding factor for the nation. Furthermore, low literacy and difficulty in balancing efficiency and right to pluralism were the leading forces in managing language and education in the constitution. Provisions of both the Constitution and the Law of Education 2008 provide the mechanism to implement the desired targets of the legislation. However, because of the sociopolitical and economic impediments, it seems difficult, if not impossible, to achieve these 
targets. Well-coordinated and serious efforts are required at primary and secondary level education so that skills of the students are enhanced and they are prepared for higher education.

In December 2001, Afghan leaders in exile signed the Bonn Agreement, forming an interim government, the Afghan Interim Administration. In 2002, Karzai was chosen president of the Transitional Islamic State of Afghanistan, whose ruling council included disparate leaders of the anti-Taliban Northern Alliance. A new Constitution, written by a specially convened Loya Jirga, or constituent assembly of regional leaders, was ratified in January 2004 (Curtis, 2008). One of the unique characteristics of the 2004 Constitution of Afghanistan is that it is rich in specifying the state's aspiration to solve the existing problems related to language and education. In this paper, before discussing provisions about language in the constitution of 2004, an ethnolinguistic sketch of Afghanistan is given, followed by the recent history of the language-related struggle and legislation. Analysis of the articles related to language would be taken first, and then the provisions for education shall be discussed. Historically because of the diverse ethnolinguistic landscape of Afghanistan, the socio-political issue always remained critical. Be it a Taliban regime or the post-Taliban era- regional languages remained a source of division among the different ethnic groups. To address this source of discord, the legislators added specific provisions in the constitution of Afghanistan 2004, to preserve the regional languages. Education is an area that was neglected by both the Taliban and Mujahidin. The fighting groups deliberately destroyed schools to keep the young generation away from the education process. Only religious, educational institutions were allowed to operate under strict control and monitoring to achieve political benefits. This paper will discuss these issues and will endeavour to suggest the way forward to reap the benefits of the constitutional provisions regarding education.

No formal official census was carried out in the state of Afghanistan. It is essential to know what the ethnic and linguistic strength of each ethnolinguistic group is for flawless language planning and policymaking. In 2008 there were reported to be 32738,376 people in Afghanistan (CIA, 2009). For each ethnic group, the estimate is Pashtun 42\%, Tajik 27\%, Hazara 9\%, Uzbek 9\%, Aimak 4\%, Turkmen 3\%, Baloch 2\%, and other 4\%. The estimated population of the linguistic groups in Afghanistan is; Afghan Persian or Dari 50\%, Pashto 35\%, Turkic languages (primarily Uzbek and Turkmen) 11\%, 30 minor languages (primarily Balochi and Pashai) 4\%. Bilingualism is prevalent in Afghanistan (CIA, 2009). However, according to the most recent estimates, which are considered authentic and recognized in Afghanistan, the total population is estimated to be 38,928,346 people, and for each ethnic group, the estimated percentage is; Pashtun 55\%, Tajik 25\%, Hazara 5\%, Uzbeks $5 \%$, Turkman 3\%, Aimoq 3\%, Baloch 1\%, and others 3\%. The ethnolinguistic composition of Afghanistan presents it as a multi-ethnic and multi-linguistic state. We can divide the spoken languages in Afghanistan into two groups, i.e., indigenous and foreign. Pashto, Dari, Turkish, Dadric, and some other languages may be included in the indigenous languages. Pashto \& Dari belong to the IndoIranian community and are the major indigenously spoken languages in Afghanistan. The Tajiks, Hazara, Uzbeks, and other ethnic groups are the main ethnic and linguistic groups, followed by the Dari. In 1986, the estimate of Pashto speakers was 6.5 million, and the Dari speakers were estimated to be around 4.1 million, with one million speakers of Hazagai dialects, Turkic languages, and Dardic languages (Majrooh \& Elmi, 1986). English, French, Russian, and German are the foreign languages on which this study will concentrate (Irshad, 2003). A foreign language can be taken as a non-indigenous language, which is learned and spoken by the indigenous population of an area (Pearsall \& Trumble, 1995). 


\subsection{3- 2001 Mujahedin and Taliban}

During the rule of PDPA, the refugee Mujahedin, with the support of Pakistan, USA, and other states, started the armed conflict in Afghanistan against the central government. The Soviet forces assisted the PDPA government. When the Soviet Union decided to withdraw its troops in 1988 from Afghanistan, the government of Afghanistan put an extraordinary resistance to Mujahidin and survived until the end of 1992. It provided enough time to surface the internal conflict between Mujahedin (Khalilzad, 1997). Pakistan supported most of the Pashtun Mujahedin, and non-Pashtun turned in most cases to Uzbekistan and Iran for help (Peimani, 2003). The ethnic conflict, in this way, assumed a linguistic dimension as well. When Burhanuddin Rabbani, a Dari speaking Tajik, was assisted by Ahmad Shah Massoud, also a Tajik, in running the affairs of Afghanistan as its president, the hold of non-Pashtun on Kabul was highly resented by the Pashtun groups (Khalilzad, 1997).

The conflict assumed the form of a civil war. Almost all educational institutes remained closed and Afghan students went to neighbouring states for education, which became one reason behind migration in many cases (Ekanayake, 2004). They had to compromise to the highly indoctrinating material available in the national languages of local schools and special schools arranged for them in the refugee camps in the host country. In many refugee schools, the standard of learning and the subverting nature of books compelled many Afghan students to seek education in the state-run schools. Many refugees went to Madrassas in Pakistan, from which later on, the raw material of the Taliban force was to be supplied. As the Taliban aimed at the control of Afghanistan in their war, they paid no attention to education. They banned the education of women during their regime (Khalilzad, 1997). During the brief tenure in power, they used Pashtu as the official language. Taliban had difficulty in communication with other linguistic groups. They expected others to accept their ideas to be right. For other language groups, it was an imposition of Pashtun culture and language (Rashid, 2000). Mostly through their unplanned political, social, and cultural imperatives, they tried to impose their vision of Islam, which was seen by other groups as linguistic and cultural imperialism.

In the Taliban period, there was a complete ban on foreigners to operate their schools and teach their language in Afghanistan. International humanitarian organizations were allowed only to give food support to the people and that too, with much suspicion. Most of the foreign language learning took place in Pakistan. Many English language institutions opened in this period in Pakistan for teaching English to Afghan students in which they eagerly took interest (Ekanayake, 2003).

\subsection{Post-Taliban}

After the end of Taliban rule, the non-Pashtun Northern Alliance took control of Afghanistan. Pashtuns were deliberately victimized as the Taliban initially. After the Bonn Agreement, the formation of the interim government had better participation of Pashtuns. Though the head of the state was appointed from Pashtuns, discontent in Pashtuns about their lesser position in army and government continued. This situation is remedied by constitutional protection. In the constitution of 2004, there is a detailed guarantee for the languages and culture of all groups. The procedure given for the judiciary (Chapter 8: Article 135) of the Constitution of Islamic Republic of Afghanistan 2004, in fundamental rights and duties of citizen (Chapter 2: Article 35 ), and the status of and function of languages in the state (Chapter 1: Article 16) shows a greater sense of responsibility in the present government toward linguistic problems. A 
particular problem that has arisen due to mass migration to the neighbouring state (Pakistan and Iran) and then the repatriation of refugees is the loss of bilingualism. It has created a problem of mutual intelligibility and communication between the Afghans brought up in Pakistan (who know a little Urdu but no Dari) and the refugees coming back from Iran who do not know Pashto (Rubin, 2005).

In post-Taliban Afghanistan, the interest in the reopening of schools is renewed. The emphasis in the reconstruction process on education provides hope for the future. Foreign language learning centres and departments are reopening in Afghanistan. English language teaching programs in schools and universities are introduced on a massive scale in the history of Afghanistan. In the present atmosphere, the English language is given more importance in comparison with other languages. English is now taught from the seventh class to the university level (Irshad, 2003). The Strategic Plan of the Ministry of Higher Education Government of Afghanistan (adopted in 2005) has emphasized the promotion of learning in the English language (Afghanistan Ministry of Education, 2005). English is gaining unique importance as an integrative force after the end of the Cold War, especially in former colonial states (Bell, 2000, p. 484). The English language is playing an integrative role in the post-conflict communities, where the newly formed groups have various linguistics differences.

The present conflict between the linguistic groups in Afghanistan, after the expulsion of the Taliban regime from Kabul, and the arrival of the US forces with operation "enduring peace" after the deadly attack on the World Trade Centre on 9/11 has thrown the national integrity of Afghanistan into doubt. In the modern age of globalization, the spread of economic, educational, social, and political backwardness into many parts of the world has necessitated the use of English for modernization. After the removal of the Taliban from power in Afghanistan, the US, along with its allies, started the process of reconstruction of Afghanistan. They are taking a keen interest in education reform to reconstruct Afghanistan on modern lines and remove the elements of alienation. A progressive and integrated Afghanistan will take birth from the debris of the conflict, which is still sporadically spoiling efforts of rebuilding Afghanistan. The objectives of the current development of education will focus on the quality of life in the light of modern changes in the world. Priority is given to the formation of a message of peace and social inclusion. This objective is to be achieved through education planning and management in which language planning will play a role (Ekanayake, 2004).

\section{Research Methodology}

This research is based on a review of the constitutional provisions together with the related facts and documents. Thus, this study can be categorized as a qualitative inquiry. Within the context of a philosophical position, the researchers have decided to take the interpretivist epistemological position. This approach is because the objective of the study is to analyze the provisions of the constitution, which is a subjective phenomenon by nature, and thus interpretivist approach is more suitable for this study (Bryman, 2016). Within this context, the study has conducted a qualitative method. The qualitative method is more suitable for the subjective phenomenon as it enables gathering and analyses of rich and detailed data for research purposes (Rubin 2016). Furthermore, inductive reasoning was chosen as a research approach in this study. The inductive approach requires the researcher to explore patterns and generalities and develop theoretical foundations. This study used an inductive approach because it allowed researchers to generalize the findings of the review (Silverman, 2016) and provided information specifically within the context of research questions. 
Furthermore, this study is based on secondary data only. The secondary data has been chosen because it is more time-efficient and cost-effective as compared to primary data. Typical sources of secondary data research included articles published in academic journals and reports published by the government, international bodies, news agencies, and educational institutions. However, secondary data and the related research methods are vulnerable to publication bias, such as the political bias of government publications and low methodological rigor of other actors. To resolve these shortcomings, this study focused on collecting data from research articles published in high quality and authentic academic journals only. The articles are published after careful analyses and editions, and therefore methodological rigor of the articles are considered higher than other sources of secondary data.

\section{Language Related Problems and the Constitution of 2004}

Afghanistan, like other developing nations, is confronting diverse linguistic problems. In the following lines, each problem is discussed regarding the latest constitution.

\subsection{Competition among the Ethnolinguistic Groups}

Scholars such as Schiffman (1996), Rahman (1980), and Kirkwood (1989) have described political rivalry as one of the reasons behind the legislative struggle of speakers of native languages. In Afghanistan, scholars like Dr. Mahmood Afshar advocated for making Dari the official and national language (Afshar, 1362.H). This poses a threat to the integration of different linguistic groups in Afghanistan. The present constitution is more representative as it guarantees representation to all language groups. It is an uphill task to do so in reality; however, a constitutional guarantee can be counted as the first step forward in the confirmation of the rights of the speakers of minority languages. Article 135 and 35 make sure that language is not used politically as a tool of disintegration.

\subsection{Unplanned Planning}

Unplanned language planning may involve language modification affected by accident, by a shared set of laissez-faire attitudes toward a language situation, and by an ad hoc solution to an immediate problem (Eggington, 2002). From the study of the Fundamental principles (Usoole-Asaasi) of 1923, 1927, 1931, and 1952, the striking absence of guidelines about the status and functions of Pashto and Dari and other minority languages expresses the lack of concern of the Afghan government about the issues of linguistic interests of the speakers of these languages and many other languages. Consideration of the linguistic problems started in the Constitution of 1964, and has been more closely treated in the Constitution of 2004.

\subsection{Nationism vs. Nationalism Equilibrium}

"Developing nations are often faced by the requirements of satisfying the two potentially conflicting needs of nationalism and nationism sociocultural and political integration respectively" (Bell, 2000, p. 467). Afghanistan finds it hard to restate the former balance between both powers in the legislation on language status, following a long civil war in which linguistic tensions played a dominant role. Hitherto, no right was acknowledged for the minority language speakers. Two languages were forced on all. Even in the two majority languages, more official weight was given to Dari. The vow to honour rights in litigation and the first language for official use in regional affairs would be a positive development to adopt 
a more flexible formulation between nationalism and nations in the Constitution of 2004.

\subsection{Ethnic Conflict}

Most of the Pashtuns think that they have been disenfranchised despite their claim and right to rule the country. Though traditionally, the ruling house came from ethnic Pashtuns, they knew little Pashtu language (Edwards, 2002). The determining factor in terms of ethnic loyalty is considered to be the language. Despite the findings of different studies showing the control of Pashtuns on government machinery, in terms of the language they are constantly shrinking, as the number of ethnic Pashtuns is far less than Pashtu speakers (CIA, 2009). Article 16, 35, and 135 in the Constitution of 2004 would positively affect lessening the ethnic conflict.

\subsection{Language}

In the absence of a comprehensive census, it is hard to estimate the literacy level in Afghanistan. Before the start of the reconstruction effort, it had touched the lowest level. Language planning relies heavily on the educational policy for its implementation and adjustment to the needs. The traditional Madrassas taught the religious curricula (whose major text used to consist of Persian readings) in mother tongue or first language (L1 or the dominant language of a speaker) or the teacher and learner. The demands of the job market were not high, and bilingualism was a desirable quality. Low literacy maintained the competition for scarce, highly paid technical jobs in the government sector and other domains of power at a minimum. It is a joint problem of education and language. The provisions about language and education promote the image of Afghans as a positive nation keen on learning and tolerance of multilingualism.

According to the 2004 Constitution, it is stated that amongst all other languages of the country, Pashto and Dari shall be the official languages of the state. Moreover, in areas where most people speak in Uzbeki, Turkmani, Pachaie, Nuristani, Baluchi, or Pamiri languages, then added to these languages, Pashto and Dari, shall be the third official language, the usage of which shall be regulated by law. Besides, the state shall design and apply effective programs to foster and develop all languages of Afghanistan. Usage of all current languages in the country shall be free in press publications and mass media. Academic and national administrative terminology and usage in the country shall be preserved (Article 16). Formation and operation of a party based on tribalism, parochialism, language, as well as religious sectarianism shall not be permitted (Article 35). If a party in a lawsuit does not know the language, the right to know the materials and documents of the case and conversation in the court shall be provided in the party's mother tongue through a translator appointed by the court (Article 135).

In comparison to previous constitutions of Afghanistan, the present constitution of 2004 is the best in the treatment of problems of language rights. Article 16 thoroughly explains the status and function of major and minor languages of Afghanistan. In other articles, which are not related to the status/function of languages, we find implications from a linguistic point of view. Those articles, which indirectly affect language rights, are Article 35 and 135. Before this constitution, Pashto and Dari were given official status. In the present constitution, along with Dari and Pashto, all current languages in Afghanistan are given this status. These include Turkmani, Baluchi, Pachaie, Nuristani, Pamiri, and others. The initial statement of the constitution reminds one of the earlier Soviet-style policy of giving equal official rank to all languages on the federal level. Such interpretation though commendable is not feasible. In the 
Soviet Union, it failed and for a country like Afghanistan with its limited resources: monitory and human, application of this policy seems a farfetched idea. This statement is, however, limited by subsequent delimitation, which offers the commonly practiced policy of using $2+1$ languages. Here two national languages are offered along with a regional language as the official language. The spirit of federalism is being accompanied by adopting a long-standing unitary state with two official languages everywhere. This spirit would help in the reduction of animosity between different ethnic groups along linguistic lines. For its implementation, however, Afghanistan would need much administrative reforms and innovations and a degree of decentralization of the lower organs of state, namely judiciary, legislative, and executive, along with education and health. Legislation and official attitude in Afghanistan have maintained some special features, which would help, understand the achievements in the Constitution of 2004.

\subsection{Education}

Despite substantial improvements during the reign of Mohammad Zahir Shah (ruled 1933-73), in 1979, some 90 percent of 'Afghanistan's population was illiterate. In 2006, an estimated 57 percent of men and 87 percent of women were illiterate, and the lack of skilled and educated workers was a major economic disadvantage (Curtis, 2008). Beginning with the Soviet invasion of 1979, successive wars virtually destroyed the education system. Most teachers fled the country during the Soviet occupation and the subsequent civil war. By 1996, only about 650 schools were functioning. In 1996, the Taliban regime banned education for females, and the madrassa (mosque school) became the main source of primary and secondary education. After the overthrow of the Taliban in 2001, the interim government received substantial international aid to restore the education system, but for the next six years, the Taliban attacked public schools wherever possible. In 2007, increased Taliban activity forced the closure of 35 percent of the schools in the southern provinces. The Taliban opened some fundamentalist schools in regions that they controlled. In 2004 and 2005, informal community education programs began in nine provinces. In 2008 about 9,500 schools reportedly were operating, at least some in every province. The Ministry of Education estimated that in 2006, 8 million children were in school, including nearly 3 million girls. Despite the renewed emphasis on educating girls, in 2008, the ratio of girls to boys in secondary schools was one to three or four, as rural families continued the tradition of educating only males. Since the end of the dogmatic Taliban era in 2001, public school curricula have included religious subjects, but detailed instruction is left to religious teachers.

Higher education also has been problematic. When Kabul University reopened in 2002, some 24,000 students, male and female, enrolled. In the early 2000s, the rehabilitation of five other universities progressed very slowly. Although seven universities were operating in 2007, only 22,700 students were active in higher education (Curtis, 2008). Accordingly, the Constitution of 2004 states that the state shall adopt necessary measures to foster education at all levels, develop religious teachings, regulate and improve the conditions of mosques, religious schools, and religious centres (Article 17). Education is the right of all citizens of Afghanistan, which shall be offered up to the B.A level in the state educational institutes free of charge by the state (Article 43). In order to expand balanced education and provide mandatory intermediate education, the state shall design and implement effective programs and prepare the ground for teaching mother tongues in areas where they are spoken.

Moreover, the state shall devise and implement effective programs to create and foster balanced 
education for women, improve the education level of nomads, and eliminate illiteracy in the country (Article 44). Besides, the state shall devise and implement a unified educational curriculum based on the tenets of the sacred religion of Islam, national culture, as well as academic principles and develop religious subjects' curricula for schools based on existing Islamic sects in Afghanistan (Article 45). Further, establishing and administering higher, general, and specialized educational institutions shall be the duty of the state. The citizens of Afghanistan shall establish higher, general, and specialized educational and literacy institutions with permission of the state. The state shall permit foreign individuals to establish higher, general, and specialized institutions following the provisions of the law. Admission terms to higher educational institutes of the state and other related matters shall be regulated by law (Article 46). Additionally, the state shall devise effective programs for fostering knowledge, culture, literature, and arts. The state shall guarantee the copyrights of authors, inventors, and discoverers and shall encourage and protect scientific research in all fields, publicizing their results for effective use under the law (Article 47).

As stated earlier, Afghanistan has to construct its education from the trash. A large number of returning Afghans, internally displaced people, hostile attitude of the Taliban, indoctrination in the existing education, and scarcity of funds are the major problems, which spoil hope of revival of education in the immediate future. However, articles 17, 43, 44, 45, 46, and 47 show the spirit to revive education in such a way that a tolerant and progressive nation would ultimately emerge. Article 17 entrusts the state with the responsibility to regulate and provide religious education. This constitution has been developed after the ousting of the extremist theocratic government uses education as a tool to combat extremism. Traditionally religious education had never been the concern of the state. Till the twentieth century, state and religion coexisted side by side without a problem. After the attack of $9 / 11$, the West became weary of the influence of Islamic extremists. State intervention would guarantee that education is not used to further the ideology of the international network of terrorists of Al-Qaeda. Article 43 ensures free education up to the BA level. Free education is not new in Afghanistan. From the early days of the twentieth-century, free education has been provided, but the number of schools was limited. Maintenance of free education up to the level of the University for a State with a huge budget deficit appears an ambitious aim. The Constitution of 2004 presents Afghanistan as a welfare state. Education up to intermediate level is made compulsory in this article, and it is to be provided in the mother tongue (first language). This article does not offer any institutional setup to achieve this aim. Article 44 ensures gender parity in education and asks for giving priority to female education. Article 45 brings the development of a unified curriculum in the domain of the state. The state has to make it non-sectarian.

Article 46 allows the foreign institutions of higher education to have a set up in Afghanistan. Article 47 sets the aim of the state to promote research in sciences and to provide it legislative immunity (apparently from clerics who term scientific research as infidelity).. The Education Law 2008 of Afghanistan provides for a mechanism that would ensure the realization of such aims. The establishment of the Ministry of Education and Ministry of Higher Education shows the sincerity of the government strengthening the role of education in the building of a nation at two different levels. In the case of Afghanistan, these Constitutional provisions show the willingness to modernize and the educational system to become a progressive welfare state. The absence of infrastructure can be the biggest hurdle in achieving such aggressive desires and targets of the government. In the absence of school buildings, it is nothing but a dream that cannot be fulfilled. Almost forty-one percent of schools in Afghanistan do not have buildings, and even if there is a building, it is insufficient to accommodate all the students (HRW, 2017). 


\section{Conclusion}

Intervention in the affairs of the Afghan government by the external elements and powers coupled with the internal political issues and using the educational institutions for political agendas negatively affected the growth of education in Afghanistan. Lack of cooperation and coordination between conventional and religious educational systems towards the demands of market, higher and technical education requirements is another obstruction contributing negatively to the growth and development of education. Among the causes of the drop in standard of education, both in terms of quantity and quality, is the fact that because of the worsening law and order condition, most of the teachers fled to neighbouring countries, creating a shortage of teachers that itself is the most alarming issue. Afghanistan's educational system does not prepare students for a career to enter the labour market after graduation. Neither does the educational system of Afghanistan prepares the students for higher education with a strong and quality academic background. Therefore, it is evident that graduates, in general, will neither be of many benefits to society nor will they fit in the labour market because of what they are learning at the educational institutions.

Thoughtful devotion at early level education will play a significant role in developing skills in the students to guide them towards a much focused and purposeful higher education. Therefore, to improve the dissemination of purposeful education, some coherence must be developed between the conventional education system and the religious education system. Through public-private partnerships, hurdles in the availability of resources can be overcome. Monitoring and evaluation of basic and general education is yet another area that has to be improved. Afghanistan needs development of a syllabus that is more focused on the practiceoriented approach. No doubt, it will better prepare the students for the job market. Faculty or teacher training programs shall be developed and introduced. Coordination between the Ministry of Education and the Ministry of Higher Education is vital, and it would be more beneficial to merge both in the best interest of education at all levels in Afghanistan.

\section{References}

Bell, R. T. (2000). Psycholinguistics. National Book Foundation.

Bryman, A. (2016). Social Research Methods. Oxford University.

Central Intelligence Agency. (2009, 30 March). Afghanistan. CIA: The World Fact Book. USA: Central Intelligence Agency. https://www.cia.gov/library/publications/the-worldfactbook/geos/af.html

Curtis, G. E. (2008). Afghanistan: A Country Profile. Library of Congress- Federal Research Division. USA.

Edwards, D. B. (2002). Before Taliban: Genealogies of the Afghan Jihad. University of California.

Ekanayake, P. B. (2004). Education in Doldrums: Afghan Tragedy. Al-Azem.

Emadi, H. (2002). Ethnic Groups and National Unity in Afghanistan. Contemporary Review. Gale Group. USA.

Haravi, N. M. (1362 Hijria). Tareekh Wa Zuban Dar Afghanistan (History and Language in Afghanistan). Tehran, Iran.

HRW. (2017). I won't be a doctor, and one day you'll be sick: girls' access to Education in Afghanistan. Human Rights Watch. https://www.hrw.org/sites/default/files/report_pdf/afghanistan1017_web.pdf 
Irshad, M. (2002). Socio-Linguistic Aspects of English in Afghanistan. Thesis, University of Peshawar, Peshawar.

Khalilzad, Z. (1997). Anarchy in Afghanistan. (G. G. USA, Ed.) Journal of International Affairs, 51(1), 52-63.

Kirkwood, M. (1989). Language Planning in the Soviet Union. London: The Macmillan.

Maillart, E. (1940). Afghanistan's Rebirth: An Interview with H. R. H. Hashim Khan in 1937. Journal of the Royal Central Asian Society, 27(2), 225-228.

Ministry of Higher Education Strategic Development Plan. (2005, March 30). Afghanistan Ministry of Higher Education; http://www.mohe.gov.af/?lang=en\&p=plan

Peimani, H. (2003). Falling Terrorism and Rising Conflicts: The Afghan "Contribution" to Polarization and Confrontation in West and South Asia. Westport, CT: Praeger.

Rahman, T. (1998). Language and Politics in Pakistan. Oxford University.

Rashid, A. (2000). Taliban: Militant Islam, Oil and Fundamentalism in Central Asia. Yale University.

Roberts, J. J. (2003). The Origins of Conflict in Afghanistan. Westport, CT: Praeger.

Rubin, A. (2016). Research methods for social work. Empowerment series. Cengage Learning.

Rubin, B. R. (2009, March 30). Afghanistan 2005 and Beyond: Prospects for Improved Stability Reference Document. Clingendael. Hague, The Netherland: Netherland Institute of International Relations. http://www.clingendael.nl/publications

Majrooh, S. B. (1986). The Sovietization of Afghanistan. Peshawar: Afghan Jehad Works Translation Centre.

Silverman, D. (2016). Qualitative Research. Sage.

Trumble, J. \&. (1995). Afghanistan. The Oxford English Reference Dictionary. Oxford University.

Wardhaugh, R. (1998). An Introduction to Sociolinguistics. Blackwell. 